\title{
Intergration Between Modern Laws With Living Laws In Rural Comunities In The Rural Economic Development
}

\author{
Ardhiwinda Kusumaputra \\ ardhiputra82@gmail.com \\ Faculty of Law, Universitas Wijaya Kusuma, Indonesia \\ Endang Retnowati \\ Faculty of Law, Universitas Wijaya Kusuma, Indonesia \\ endangretnowati49@yahoo.com
}

\begin{abstract}
The purpose of this study is to find and analyze the integration between state modern laws and the living laws in the village, in its relation with national economic development and to find and analyze the ways to optimize national economic development through rural autonomy. The research method used is normative juridical, using legal material. The integration between state modern laws and the living law in the rural communities is by giving attention and accommodating the living laws in the rural communities especially in the economic order in the village including the establishment of Village-Owned Enterprises (BUMDes). In the formation of rules or laws relating to the economy or village empowerment, it should not only be juridical aspect that is prioritized but the philosophical, and sociological aspect of rural communities needs should be used as foundation . Reflection on the Pancasila understanding is also very necessary. This is because Pancasila is transformation result of various legal principles in Indonesia, Optimizing village economic development through rural autonomy by making improvements, and empowering all the potential of the village in particular the human resources and natural resources.
\end{abstract}

Keywords: Integration, Modern Law, Living Law, Village Economic Development.

\section{INTRODUCTION}

Village is governmental unit that is recognized, respected and protected within the framework of the Unitary State of the Republic of Indonesia. Constitutionally, the existence of village is accommodated based on Article 18B of the 1945 Constitution of the Republic of Indonesia. The existence of provisions in the constitution gives the consequence that the village is important part of the country. It gives the basic understanding of the constitution by KC Wheare ${ }^{1}$, that "constitution is used to describe the whole system of government of a country". Likewise, CF Strong ${ }^{2}$, " a constitution may be of the highest authority, the right of governing, and the relations between the two are adjusted". This understanding leads to an understanding that the village is part of a system of government that also has power which is limited by legislation.

As a form of derivative regulation from the 1945 Constitution of the Republic of Indonesia, the Law Number 6 Year 2014 concerning Villages was formed (Law Number 6 Year 2014). The emergence of Law Number 6 Year 2014 is one of government steps to maximize the village role through rural autonomy.

The definition of village as referred in Article 1 number 1 of Law Number 6 Year 2014 is:

\footnotetext{
${ }^{1}$ K.C. Wheare, Modern Constitution, London: Oxford University Press, 1966, page. 1

${ }^{2}$ C.F. Strong, Modern Political Constitution, An Introduction to the Comparative Study of Their History and Existing Form, London: Sidgwick \& Jackson Limited, 1966, page. 11.
} 
Villages are village and traditional villages or what are called by other names, hereinafter referred to as Villages, are legal community units that have territorial limits that are authorized to regulate and manage government affairs, interests of local communities based on community initiatives, origin rights, and / or rights traditionally recognized and respected in the system of government of the Unitary State of the Republic of Indonesia

Based on this understanding it can be understood that through Law Number 6 Year 2014, the government tried to homogenize the terms village and traditional village as "village". When mentioning the term of village, it means covering (conventional) villages and also traditional villages. If we look at the uniformity of this term it can actually cause ambiguity, because between villages and traditional villages still have different characteristics, for example the village leader. Besides this terms uniformity can actually eliminate the characteristics of these villages. But regardless the terminology, the village still has autonomy that must be carried out in accordance with applicable law.

Rural autonomy is concept that was born based on the village initiative, not gift from the state (government). Rural autonomy even became basic idea in shaping the Indonesian State and also implementing decentralization. Rural autonomy should not be understood as derivative or branch of regional autonomy. ${ }^{3}$ Recognition of rural autonomy according to Bagir Manan $^{4}$, there are two things that must be considered. First, rural government does not have to always use the name village. Allowed to use names according to the character of village customs, such as hamlets, clans, nagari, meunasah, gampong, and so on. Second, recognition of genuine autonomy.

The village existence as a government, should be able to be utilized by the government to increase national growth, both in the economic, social, cultural and political fields. This is considering that historically, villages have the ability to be independent in carrying out village management. Moreover, every village has unique potential, both the potential of natural resources and human resources. The values that live in the rural communities are also able to bring the village as an advanced community. Of course to create such conditions, it needs guidance from various elements, for example through the regency/ city government.

The problem is recognition of rural autonomy has not yet been fully delivered, meaning that the government is still hesitant to maximize rural autonomy. This can be seen from the arrangement in Law Number 6 Year 2014, for example in Article 90. Villages can manage village natural resources, but it turns out that the authority for managing natural resources is mostly borne by the regional government through other regulations. It is as if the village is given authority, but it is limited by other regulations. As result the village is unable to develop independently.

It has also been formulated that each village has Village-Owned Business Entity (BUMDesa) which is formed and managed by the village. But in fact there are still many BUMDesa which have not been maximally empowered. This is due to the community and the village apparatus do not understand correctly related to BUMDesa. Follow-up from the central government or the regional government to provide guidance on BUMDesa is still not carried out sustainably. As result this BUMDesa actually seems dead, unable to develop. Even if the BUMDesa is properly developed, it can lift village economic growth, which also directly impacts national economic growth. Especially in Article 90 letter c of Law Number 6 Year 2014, it is stated that BUMDesa is a priority in managing rural natural resources. The government and regional governments have an obligation to provide support in the development of BUMDesa, both in the form of material support, as well as guidance.

\footnotetext{
${ }^{3}$ Ateng Syafrudin and Suprin Na'a, Republic of the Village The Struggling of Traditional Law and Modern Law in Rural autonomy Design, Bandung: Alumni, 2010, p. 10-12.

${ }^{4}$ Bagir Manan, Welcoming the Dawn of Regional Autonomy, Yogyakarta: Center for Legal Studies (PSH) FH-UII, 2001, p. 161-162.
} 
Regulations or policies established at the central and provincial and regency / city levels, often still clash with customary law that applies in the villages. For example, when in Law Number 41 year 1999 concerning Forestry (Law 41 of 1999), it states in Article 5 that customary forests are part of state forest. This provision actually provides gap to sell the forest on behalf of the state to the investors to exploit the forest. Even though this is contrary to the prevailing customary law and local wisdom. Often when faced with such conditions, customary law becomes excluded. As result, the rights of indigenous villagers have been violated and harmed. ${ }^{5}$

All these problems increasingly show if the government is still not serious in empowering villages. Even though through rural autonomy which is maximally empowered, it can provide significant economic growth for the country. Especially considering the village potential. Therefore, this paper focuses on optimizing national economic development through rural autonomy, based on existing laws and concepts.

According to the introduction, the discussion will cover "How is the integration between the state modern law and the living laws in the village, in relation to national economic development? and How to optimize national economic development through rural autonomy?"

\section{RESEARCH METHODS}

The research method used is normative juridical, normative juridical is research based on the analysis of legal materials in the form of several legal principles and several legal theories as well as laws and regulations that are in accordance with the problems in this study.

\section{RESULT AND DISCUSSION}

\section{a. Rural Autonomy And National Economic Development}

\section{i. Rural Autonomy Essence}

Etymologically the term village comes from the word "swadesi" (in Sanskrit) which means an independent, autonomous region, place or part. ${ }^{6}$ Villages are also seen as group of people located in a region with certain limits. Among individuals has very strong social attachment. The value of mutual cooperation and deliberation are characteristic of the rural communities. ${ }^{7}$ Even the local wisdom in the village is also very well maintained.

By Mashuri Maschab ${ }^{8}$, there are at least three perspectives on the village. First, sociologically where the village is described as residents community who live permanently in environment with homogeneous pattern of life. Secondly, it is economically that the village as community environment that seeks to fulfill its daily needs from what nature provides around it. Third, politically, namely as government or power organization that has authority because it is part of the state

Based on this understanding, it can be concluded that in essence the village is form of real, democratic and autonomous government, has tradition and law on its own initiative and a source for the formation of higher power (state). Therefore the state must recognize and respect the rural government entity.

${ }^{5}$ Agus Sahbani, "The Constitutional Court Affirms Indigenous Forests Not State Owned", 2013, <http://www.hukumonline.com/ berita/baca/lt5194c9568b9f7/ mk-tastian-hutan-adat-bukan-milik-negara>, [05 / 01/2017].

${ }^{6}$ P.J. Zoetmulder works with S.O. Robson, Old Javanese Dictionary of Indonesia, Jakarta: Gramedia Pustaka Utama, 2006, p. 212, which has been quoted by Ateng Syafrudin and Suprin Na'a, Rural republic, Op.Cit., P. 2.

${ }^{7}$ Soerjono Soekanto, Introduction to Sociology, Jakarta: Rajawali Press, 2010, p. 55.

${ }^{8}$ Mashuri Maschab, Politics of Rural government in Indonesia, Yogyakarta: PolGov, Research Center for Politics and Government, Department of Politics and Government, FISIPOL UGM, 2013, p. 1-3. 
Rural autonomy is genuine, round and intact autonomy and is not a gift from the government. ${ }^{9}$ The existence of rural autonomy is at the core of the concept of the Unitary State of the Republic of Indonesia (hereinafter referred to as NKRI). This is also considering that the village was born before the existence of sovereign NKRI. ${ }^{10}$ The existence of such rural autonomy does not mean that the village is separated from the relationship between the central government and regional government. All remain in touch with each government whose position is higher than village, both in carrying out the authority and task of assistance. This is intended as form of government coordination, in order to create a more organized governance.

Rural autonomy recognizes the existence of origin rights, which is also a source of village authority. Rights origins of a distinctive character owned by the village, and men become one of the elements that will differentiate regional autonomy. This origin right is a form of government recognition to the village to be able to explore and maintain the authority that exists in the village, by looking at the historical perspective of the village. This origin right also became the traditional identity of the village and became part of the lex naturalist. ${ }^{11}$ The existence of living law in the village also becomes part of the rights of origin guaranteed by the state. Even some of the living law was adopted in positive law to strengthen the existence of the village.

As consequence of recognizing this rural autonomy, the interests inherent in the village cannot be immediately excluded. Especially if it is related to law. Living law in rural communities, cannot be directly excluded by state law.

\section{ii. Relations between Rural autonomy and National Economic Development}

Rural autonomy gives the village the freedom to be able to manage and manage the affairs of the village household in accordance with applicable law. This is so that the village is able to develop independently in various sectors, especially in the economic sector. Villages with autonomy can become one of the motors and pillars in national economic development. Statistically, the number of villages in Indonesia in 2016 reached $81,253 .{ }^{12}$ This amount will certainly play an important role in the development of the national economy .

The national development agenda that is embodied in the National Long-Term Development Plan (RPJPN) and the National Medium-Term Development Plan (RPJMN), has provided space to make villages the priority part of national economic development. Of course this is also evidence that building the economy from the lowest government sector gives more value for effectiveness.

Rural autonomy as one of the driving forces and pillars in national economic development, needs to get support. This support is provided by the government, both central and regional. One form of support is to give the village legitimacy to develop independently. Article 19 of Law Number 6 Year 2014 relating to village authority is also a support from the government. Including when formed ministerial regulation that regulates various technical matters in the implementation of village governance. Providing clear legitimacy to this village becomes important part, because Indonesia is legal state, so that everything related to the administration of government must have a clear legal basis. This is also intended to avoid abuse of power from the authorities.

The relationship between rural autonomy and national economic development is sustainable, meaning that the role of rural autonomy is not only stopped or limited at certain time. Through the existence of rural autonomy, it certainly plays role in economic

\footnotetext{
${ }^{9}$ HAW. Widjaja, Village Autonomy Is Original, Round and Whole Autonomy, Jakarta: Rajawali Press, 2008, p. 165.

${ }^{10}$ Ateng Syafrudin and Suprin Na'a, Rural republic ... Op. Cit., P. 11.

${ }^{11}$ Ibid., P. 45.

${ }^{12}$ Data obtained from www.bps.go.id.
} 
development. Villages can empower their communities to develop rural potential, for example by forming business activities through BUMDesa. Such activities would also be in line with the vision of Indonesia in creating public welfare.

\section{b. Rural Autonomy Based National Economy Development \\ i. Integration of State Modern Law Integration with Living Laws in Villages in the Context of National Economic Development}

Law is a means to create order in society. Roscoe Pound ${ }^{13}$ argues that "the first and simplest idea is that law exist in order to keep the peace in a given society, to keep the peace at all events and at any price". If the law has been able to create safe conditions in the community, then all aspects of life in society will also become more organized. Minimizing conflicts in the community.

If examined further from the point of view of legal functions, there are at least four basic functions, namely: ${ }^{14}$

1. Law as maintaining order and security;

2. Law as a means of development;

3. Law as a means of enforcing justice;

4. Law as a means of education in the community.

The four functions also serve as guidelines in the formation of law. In the process of establishing the law, it must be ensured that the law established is able to carry out its functions appropriately. Economic development cannot be separated from legal development, because between economy and law are two things that influence each other. ${ }^{15}$

In the New Order era, economic experts, economic actors, and authorities viewed the law as a hindrance to the implementation of economic activities. At that time the law was not used as a foundation, guide and enforcer of activities in the economic field. The existence of the law was damaged by the authorities, only to defend the new order political economy interests that served the interests of developed countries. As a result the law moves more static, and seems unable to adjust to developments. As time went on, slowly the authority of the law began to be seen to create a conducive economic climate and to attract investment. This also led to the development of law in Indonesia, becoming modern law. ${ }^{16}$

There are three basic characteristics of modern law, including: ${ }^{17}$

1. Secular and pragmatic in nature;

2. Oriented to interests and is a business carried out consciously by humans;

3. Open bersifat and contain elements of change that are done intentionally.

It is further understood that modern law is in the written form. Its formation is considered more rational by prioritizing benefits. More structured (hierarchical), so that the implementation is clear and directed. ${ }^{18}$ However, the modern law about economic development are more oriented towards the interests of capital. As result the living laws in the rural communities ( living law ), actually becomes oppressed. Even though this modern law should be able to accommodate all interests, including when faced with living law .

When looking at the concept of unification of Indonesian law, living law (or also known as customary law), becomes one of national law elements. Obviously this provides consequence that the government may not unilaterally ignore the existence of living

${ }^{13}$ Roscoe Pound, An Introduction To The Philosophy of Law, New Haven: Yale University Press, 1961, p. 33.

${ }^{14}$ Sunaryati Hartono, Indonesian Development Economics Law, Bandung: Binacipta, 1988, p. 10.

${ }^{15}$ Dewa Ayu Made Kresna Puspita Santi and I Gusti Ngurah Parwata, "Legal Functions in Economic Development", Article Not Published, 2013, p. 2.

${ }^{16}$ Adi Sulistiyono \& Muhammad Rustamaji, Economic Law As Commander, Surabaya: Masmedia Buana Pustaka, 2009, p. 16.

${ }^{17}$ Ronny Hanitijo Soemitro, Legal Sociology Problems, Bandung: Sinar Baru, 1984, p. 82-83.

${ }^{18}$ Ibid, p. 55. 
law. ${ }^{19}$ Building economic law does not only speak of general interests, but also needs to consider the traditional rights of the community. Moreover, constitutionally the state has an obligation to respect the traditional rights of the people.

Living law is part of rural community as an autonomous entity, set the life system, which is born from and within the community and maintained by the community. Explanation of chapter IV of the Basic Law (before the amendment) implies that in Indonesia there are approximately 250 zelfbestuurende land scappen and volkgemen-scappen which have their own social systems and have strong relations with land, management of natural resources, and power to maintain values local values or local wisdom. ${ }^{20}$ Through this living law, it has actually given the village the freedom to develop independently.

There are four basic characteristics possessed by living law, including: ${ }^{21}$

1. Has strong collectivism nature;

2. It has magical-religious pattern that is related to the life view of the indigenous people;

3. Covered by concrete thoughts, very concerned about the number and repetition of concrete relationships that occur;

4. Visual, meaning that legal relations are deemed to occur only if they are determined by a bond that can be seen or with visible signs.

Living Law experienced huge shock in the current era of globalization. The shock is caused by social changes in society which cover various aspects of life, including the economy. Intimidation of modern law which lacks the interests and existence of living law, makes existence increasingly eroded. ${ }^{22}$ An example is when the indigenous forest was dominated by the government under Law 41 of 1999, and sold to the capitalist, the traditional rights of rural communities be eliminated. This condition is even more aggravated by the absence of the rural communities in utilizing the forest land. Even investors who have taken control of forest land, actually carry out massive exploitation and ignore the values of local wisdom that live in the surrounding community. ${ }^{23}$ As result, the economic growth of the rural communities has died. Land that could have been used for their interests was taken away. This is where the modern legal position of the state actually acts authoritarian towards living law.

Such conditions should not have happened in the legal establishment (law making process) if the state pay attention to the function of the law itself. In addition there are three aspects (geldingsgrondslag van strafrecht) should also be considered fundamental in the creation of new laws, namely:

1. Fulfill the philosophical aspects, namely laws that are considered to fulfill sense of justice (philosophofische geldingsgrondslag);

2. Fulfill sociological aspect, that the laws established acceptable to society (sociologische geldingsgrondslag);

3. Juridical aspects (juridische geldingsgrondslag), namely that the law is the result of formulation by authorized body, and does not conflict with higher law. ${ }^{24}$

These three aspects must be met cumulatively, because if there is one aspect that is lacking, it can affect the validity of the law. Often in legal formation these aspects are not

${ }^{19}$ Sunaryati Hartono, Politics of Law Towards a National Economic Law System, Bandung: Alumni, 1991, p. 61-65.

${ }^{20}$ Herman and Manan Sailan, Introduction to Indonesian Law, Makassar: UNM Publishing Agency, 2012, p. 60 .

${ }^{21}$ Ronny Hanitijo Soemitro, Problem ... Op.Cit., P. 54.

${ }^{22}$ Satjipto Rahardjo, Face of Law in the Reformation Era: (Scientific Work Collection of Welcoming 70 Years Prof. Dr. Satjipto Rahardjo, S.H. Bandung: Publisher of PT Citra Aditya Bakti, 2010, p. 51).

${ }^{23}$ Muhammad Agung Riyadi, "Customary Forests are not State Forests, AMAN Urges the Government to Implement MK35", <http://www.gresnews.com/berita/hukum/211163-hutan-adat-bukan-hutan-negara-amandesak-pemerintah -stand-mk35 / 0 />, [05/01/2017].

${ }^{24}$ T. Boestomy, Civil Law and State Administrative Law in Theory and Practice, Bandung: Alumni, 1994, p. 56-57. 
properly considered. Studies conducted through the establishment of academic texts, still not able to be carried out in full. Even if we look at Law Number 12 of 2011 concerning the Establishment of Laws and Regulations (Law 12 of 2011), it is emphasized the need to establish academic texts before forming legislation. Of course, by adhering to these three basic aspects, we can explore the living law in society.

It is necessary to re-reflect, that in the law integration in economic development, it must be remembered and based on Pancasila in accordance with Article 2 of Law 12 Year 2011. This is considering that Pancasila is transformation of all legal rules in Indonesia. Understanding Pancasila must be comprehensive. First, based on the first principle, the established law must be able to respect and accommodate spiritual values that live in the rural communities. This is important because living law has religious characters. This character also gives a positive impact on the implementation of law in the rural communities. State law (through legislation), must be able to accommodate this interest.

Second, based on the second principle that there is a traditional right of the rural communities that must be protected. This is very closely related to humanity. The traditional rights of village people are lex naturalis which cannot be separated from the existence of the village. If the modern law of the state ignores these rights, then the law can be categorized as violating human rights. Especially if you remember that traditional rights are not a gift from the state, giving birth comes from the life of the rural communities, even long before the state was formed.

Third, based on the third principle the need to maintain unity through a balance of interests. A country must consist of various kinds of interests, but the state must also be able to balance these various interests. In connection with this economic development, on the one hand the country is faced with the interests of investors who want to occupy resources in the territory of Indonesia. On the other hand, the state is also faced with the existence of rural communities with the autonomy of their villages. The middle road that can be taken is that the government forms a policy by empowering rural communities by utilizing investors. Land rights must not be transferred to investors. In this position, the firmness of the government needs to be done through the legal policy that is formed, because it becomes a legitimacy in implementing economic development based on rural autonomy. Do not let the unity of the state become broken just because it emphasizes capitalist interests.

Fourth, in accordance with the fourth principle, it is necessary to invite the rural communities to have a dialogue in the formation of law. The government is required to go down to meet the community members and conduct deliberations to reach agreement with the rural communities directly. This is important, considering that often in the formation of legislation and policies, the government does not invite its people to dialogue. Even though through dialogue in the discussion forum, it can be clearly known the interests of the villagers, especially to learn and understand the living laws in the village.

The fifth, based on the fifth precept, is like a spring. Everything that is done must bring out the value of social justice. Of course this social justice is economic justice for the community. Villagers get the right to receive benefits from what they do. However, people's welfare is a subject that must be prioritized by the government.

If all these descriptions are able to be actualized, then the integration between the modern laws of the country and the living law in society, will be realized correctly. The norm conflict between state law and living law will also be avoided. The power inherent in the state must be able to be applied appropriately so as to create a balance of various stakeholders.

\section{ii. Rural autonomy as Foothold in Optimizing National Economic Development}

At present the government is being intensified to prioritize the implementation of rural autonomy. The government is trying to develop the village as the axis of the national economy. This is done considering the enormous potential of the village. The large number of 
villages, and the distinctive characteristics of the village, made the village trusted to be able to support national economic development.

Historically, the program to develop village has actually begun since the beginning of Indonesian independence. The government at that time compiled a regulation which was used as the basis for village to run the government autonomously, namely Law Number 22 Year 1948 concerning the Establishment of Basic Rules Regarding Self-Governing in Regions Entitled to Manage and Manage Their Own Households ( Law 22 Year 1948). The instability of the country conditions at that time, resulted in the regulation not being implemented in its entirety. Along with the development of the regime that occurred, policies to develop the village are still being carried out. It's just not yet a priority agenda, because Indonesian government before the reform era was still more focused on centralistic development. ${ }^{25}$

The idea of national economic development through the village was also emphasized by Hatta. The economic democracy of a country should also be carried out to the rural government environment. This will have significant impact on national economic growth. Villages have distinctive autonomy characteristics. However, to be able to achieve this goal there is a need for guidance from the district / city government, until finally the village is truly able to carry out its autonomy in its entirety. ${ }^{26}$

Autonomy basically means independence to regulate and manage the affairs (the household) itself. ${ }^{27}$ DO Adeyemo ${ }^{28}$ argue, that:

"Local Government autonomy is perceived as local self-government or grassroots democracy". This grassroots democracy is a company that has a very high level of opportunity to participate in determining their own destiny. But it does not have complete autonomous or complete local self-government within sovereign states. If local governments were completely autonomous they would be sovereign states."

Based on this definition, it can be understood that in principle autonomy is a form of freedom for the region to regulate government affairs, but not in the free sense. This also raises the need for coordination between governments. Autonomy is also at the root of democracy, so it is appropriate if the implementation of economic democracy must also come down to the rural government. . In line with this understanding, Emezi's view of autonomy is furthermore ${ }^{29}$, that:

"System of local administration under local communities that is organized to maintain law and order, provides some limited range of social amenities, and encourages cooperation and participation of the population towards the improvement of their conditions of living. It provides the community with the formal organizational framework of the which enables them to conduct e ffectively Reviews their affairsfor the general good ".

This autonomy will encourage each village to increase economic growth. Increasing community participation in building business sector facilitated by the rural government. Of course this will greatly affect the level of community welfare. However, the people's welfare level is also strongly influenced by their economic conditions.

Understanding economic development through rural autonomy, must also be followed by the quality human resources development. Precisely the development of the human

\footnotetext{
${ }^{25}$ Nurcholis Hanif, Growth and Implementation of Rural government, Jakarta: Erlangga, 2011, p. 215.

${ }^{26}$ Muhammad Hatta, People's Sovereignty, Autonomy \& Democracy, Bantul: Kreasi Wacana, 2014, p. 2123 and 72

${ }^{27}$ Bagir Manan, Relations between Central and Regional According to the 1945 Constitution, Jakarta: Pustaka Sinar Harapan, 1994, p. 21.

${ }^{28}$ D.O. Adeyemo, "Local Government Autonomy in Nigeria: A Historical Perspective”, 10: 2 Journal Social Science, 2005, p. 79.

${ }^{29}$ Emezi Cleus 1984. "Local Government in Historical Perspective”, 2: 2 Nigerian Journal of Public Administration and Local Government, 1984, p. 51.
} 
resources quality is the main key in economic progress. Without the quality of qualified human resources, it will be difficult to build economy. Community empowerment must be carried out continuously. Through the assistance provided by the regency / city government along with the rural government, it continues to provide forms of training to the community, such as soft skills, or business development tricks.

The classic paradigm that is still often attached to rural communities is the desire to urbanize. They make fortune in big cities with limited capabilities. They were of the view that there was nothing more in the village to do, even though there were not able to give more results to them. ${ }^{30}$ This paradigm must be changed, through community empowerment and training. Provide education both theory and practice to be able to develop personal abilities.

Arthur Dunham ${ }^{31}$ formulate community development as "organized Efforts to improve the conditions of community life, primarily through the enlistment of self-help and cooperative effort from the villagers, but with technical assistance from the government or voluntary organizations." Based on these descriptions can be known the characteristics of rural communities development are : first, the existence of organized businesses to improve the living conditions of the community, secondly, there is an increase in the efforts of cooperation and mutual cooperation in carrying out development; third, the development of rural communities requires technical assistance from the government and voluntary organizations.

Arthur Dunham further ${ }^{32}$ propose four elements of rural communities development, namely: (1) program plan with focus on the total needs of rural communities; (2) technical assistance; (3) integrating various specialties for the help of the community ; and (4) a major emphasis on self-help and participation by the residents of the community. The four elements emphasize the development of rural communities is planned program, focusing on community needs, requires technical assistance from experts from various fields, and prioritizes mutual cooperation activities to foster active participation of the community in development. This is certainly in accordance with the characteristics of rural communities in Indonesia, namely kinship and mutual cooperation. Thus, in the context of the development of human resources it is necessary to involve various elements, both government, academics and practitioners.

As formulated in Law Number 6 Year 2014, that villages can form BUMDesa which is intended as a place to conduct business activities. The existence of BUMDesa is very instrumental in increasing village economic growth. Moreover, through BUMDesa it can manage natural resources or other potential owned by the village, to be used as a source of the economy. In accordance with the objectives of establishing BUMDesa, among others:

1. Encouraging rural economic development;

2. Increase rural original income;

3. Increase the creativity and opportunities of productive economic businesses in lowincome rural communities;

4. Encouraging the development of informal micro-enterprises.

The implementation of BUMDesa is still not optimistic, due to several aspects. First, the lack of support from the rural government as well as the central and regional governments in empowering BUMDesa. Although the central government provides financial assistance to the village, the funds cannot be absorbed maximally to develop the village economy. Direct guidance is needed in terms of implementation. Second, the level of understanding of the village apparatus about BUMDesa and the map of village potential is still low. Although the

30 Ali Hanapiah Muhi, "Phenomenon of Village Development", Jatinangor: Institute of Domestic Administration, 2011, p. 9-10.

${ }^{31}$ Arthur Dunham, Community Welfare Organization, Principles and Practice. New York: Thomas Y. Crowel Company, 1958, 40-41.

32 Ibid.,p. 43-44. 
Regulation of Regional Development, and Transmigration Minister Number 4 Year 2015 has been established concerning the Establishment, Management and Management, and Dissolution of Village-Owned Enterprises (Permendesa Number 4 Year 2015), it does not automatically provide a complete understanding to the community and its apparatus. Third, the level of community participation is still lacking. The community is reluctant to participate because the tangible results of the BUMDesa implementation have not been seen. On the other hand, there are still many people who do not understand the technical procedures for implementing BUMDesa. Fourth, the lack of facilities and infrastructure owned in the village environment.

In the first stage to optimize BUMDesa, it is necessary to study the potential of the village. Certainly not every village in Indonesia has the same potential . Even though the village does not have any potential at all, the study can provide direction to develop the village economy. Furthermore, there is need of mobilizers in the village environment. In village there must be formal and informal leaders. Formal leaders are those who fill leadership positions such as village heads, tribal leaders, or other terms, while informal leaders are those who have the willingness and ability to mobilize the community.

The village head or village leader has role in issuing regulations or policies that are the legal basis for developing the village economy. This legal basis is important, because this is means to provide clear legitimacy. Without this legal basis, it can potentially lead to conflict. The role of community leaders is more technical in nature, becoming an example in initiating the establishment of BUMDesa. This activity is carried out after structuring the human resources sector. In this position, there is also a need for a form of structural coordination of the government, even involving the financial sector. This is intended so that no action can occur that can harm village finance.

The rural government involvement as the BUMDesa founder with the community is expected to meet the Minimum Service Standards (SPM). The rural government must take part in the establishment and implementation of BUMDesa. As legal entity, BUMDesa grounded in the rules and applicable legislation, and in accordance with the agreement that is built in small rural communities. If the BUMDesa is able to be carried out properly and sustainably, it is possible that there will be drastic growth of national economy.

\section{CONCLUSION AND SUGGESTION}

\section{a. Conclusions}

1. Integration that can be done between the state modern law and living laws in the rural communities (living law) by not ignoring the existence of living law. It is importance to revisit the basic legal functions. Especially when there is process of forming the law, the philosophical, sociological and juridical aspects must be studied in depth. Reflection on the understanding of Pancasila is also very necessary. This is because the Pancasila is transformation result of various legal principles in Indonesia.

2. Optimization is done by improving and empowering the human resources and natural resources quality. These actions are main things that must be done first. Followed by building Village-Owned Business Entity (BUMDesa), which was formed and managed by the village in accordance with existing rules in the rural communities. The rural government can establish village regulations that are binding in accordance with the rules that live in the village in the implementation of village economic development. 


\section{b. Suggestion}

After doing analysis through this writing, the author can provide some suggestions, among others:

1. When legislation is faced with living law, then the regulation cannot immediately apply superiorly and exclude living law. It is necessary to conduct prior assessment for the implementation of these laws and regulations.

2. It is necessary to reflect Pancasila as the fundamental foundation and source of all sources in the formation of Indonesian legislation. This Pancasila understanding must be wholly.

3. The existence of living law must be truly respected and become the whole foundation in the implementation of rural autonomy.

4. Economic development in the village, must be carried out through appropriate strategies and coordination. It needs first to make improvements to the human resources quality. At the same time, potential assessment that is owned or can be developed in the village as the economic source. Then manage the Village-Owned Enterprises. All of this was done with the involvement of central, regional and rural governments, communities, academics, and practitioners.

\section{REFERENCES}

\section{Book}

Adi Sulistiyono \& Muhammad Rustamaji, Economic Law As Commander, (Surabaya: Masmedia Buana Pustaka, 2009).

Ali Hanapiah Muhi, "Phenomenon of Rural Development", (Jatinangor: Institute of Domestic Government, 2011).

Arthur Dunham, Community Welfare Organization, Principles and Practice. (New York: Thomas Y. Crowel Company).

Ateng Syafrudin and Suprin Na'a, Rural Republic the Struggling of Traditional Law and Modern Law in Rural Autonomy Design, (Bandung: Alumni, 2010).

Bagir Manan, Relations between Central and Regional According to the 1945 Constitution, (Jakarta: Pustaka Sinar Harapan, 1994).

Bagir Manan, Welcoming the Dawn of Regional Autonomy, (Yogyakarta: Center for Legal Studies (PSH) FH-UII, 2001).

CF Strong, Modern Political Constitution, An Introduction to the Comparative Study of Their History and Existing Form, London: (Sidgwick \& Jackson Limited, 1966).

Dewa Ayu Made Kresna Puspita Santi and I Gusti Ngurah Parwata, "Legal Functions in Economic Development",( Article Not Published, 2013).

Hanif Nurcholis, Growth and Implementation of Rural government, (Jakarta: Erlangga, 2011).

HAW. Widjaja, Rural autonomy Is Original, Round and Whole Autonomy, (Jakarta: Rajawali Press, 2008).

Herman and Manan Sailan, Introduction to Indonesian Law, (Makassar: UNM Publishing Agency, 2012).

KC Wheare, Modern Constitution, (London: Oxford University Press, 1966).

Mashuri Maschab, Politics of Rural Government in Indonesia, (Yogyakarta: PolGov, Research Center for Politics and Government, Department of Politics and Government, FISIPOL UGM, 2013).

Muhammad Hatta, People Sovereignty, Autonomy \& Democracy, (Bantul: Kreasi Wacana, 2014).

Ronny Hanitijo Soemitro, Legal Sociology Problems, (Bandung: Sinar Baru, 1984).

Roscoe Pound, Introduction to Philosophy of Law, (New Zealand: Yale University Press, 1961). 
Satjipto Rahardjo, Face of Law in Reformation Era: (Collection of Scientific Works Welcoming 70 Years Prof. Dr.Satjipto Rahardjo, SH, (Bandung: Publisher of PT Citra Aditya Bakti, 2010).

Soerjono Soekanto, Introduction to Sociology, (Jakarta: Rajawali Press, 2010).

Sunaryati Hartono, Indonesian Development Economics Law, (Bandung: Binacipta, 1988).

Sunaryati Hartono, Politics of Law Towards a National Economic Law System, (Bandung: Alumni, 1991).

T. Boestomy, Civil Law and State Administrative Law in Theory and Practice, (Bandung: Alumni, 1994).

\section{Other sources}

Agus Sahbani, "The Court Affirms Indigenous Forests Are Not State Owned", 2013, $<$ http://www.hukumonline.com/berita/baca/lt5194c9568b9f7/mk-tastian-hutan-adatbukan-milik-negara>, [05 / 01/2017].

Muhammad Agung Riyadi, "Customary Forests are not State Forests, AMAN Urges the Government to Implement MK35", <http://www.gresnews.com/berita/hukum/211163hutan-adat-bukan-hutan-negara-aman-desak-pemerintah -stand-mk35 / 0 />, [05/01/2017].

Emezi Cleus 1984. "Local Government in Historical Perspective", 2:2 Nigerian Journal of Public Administration and Local Government, 1984.

DO Adeyemo, "Local Government Autonomy in Nigeria: A Historical Perspective", 10: 2 Journal of Social Science, 2005. 